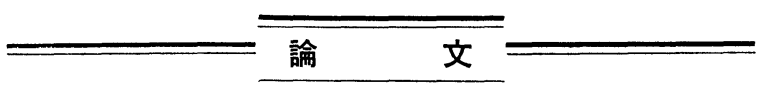

\title{
空気調和ガラス室内外の蒸散比較*
}

\author{
小倉祐幸 \\ （日本専売公社秦野たばこ試験場）
}

\begin{abstract}
Comparison of Transpiration rates at the Inside and Outside of the Air-conditioned Glasshouse.
\end{abstract} Yūkō Ogura

(Hatano Tobacco Experiment Station, Japan Monopoly Corporation, Hatano)

空気調和ガラス室に拈ける植物からの蒸散量は空気調 和器の潜熱負荷となるので, 空調器の除湿能力を設計す るに当つて，この量をできるだけ正しく見積もることが 必要となる。一方, 蒸散量は室の温湿度条件によつて左 右されるのであるから, 両者の関係は相互作用的であ る。

ファイトトロンのガラス室などでは, 現在, 一般には 湿度調節は十分に行なわれないばかりか，その他の条件 もなお不十分なものが多い。すなわち，多くは風速・風 向は昼夜の別なく年中一定であり, 温度を一定に保つた めには夏は冷凍機により循環および新鮮空気は除湿され て低湿に傾むぎ，また冬は暖房機により䁔められて,や はり低湿になり易い傾向がある。

このように室内の環境諸条件は戋場とはかなり異なる ので, 蒸散もまた室の内外で相当に異なることが予想さ れるので，このことを確かめるため，実験を行なつた。

\section{1. 実験方法および結果}

実験は秦野たばこ試験場 E 48号ガラス室で行なつた， この室は 5 月〜 10 月は冷凍機, 11 月〜 4 月は䁔房機の運 転により，打抾む称昼 $25^{\circ} \mathrm{C}$ ，夜 $18^{\circ} \mathrm{C}$ の条件に，また， 水スプレー加湿器により湿度は50 90\%に空気調和され て扔り，タバコをa $/ 5,000$ ポットでコンクリートベッド 上に $35 \mathrm{~cm}$ 間隔に並べて, 年間継続的に繰り返し栽培試 験を行なつている。

室内外の温湿度は 1 週間巻きの自記記録計（パイメタ ル・毛髮)により連続記録した。植物からの蒸散は毎朝 9 時にポット全重量を秤量して求めた。また, この時, 土壤水分が生育に好適な最大容水量の約 $60 \%$ になるよう

* 昭和 44 年 7 月 4 日関東支部第 2 回例会にて発表
に欠損分を注水補給した。この場合，土壤表面からの蒸 発もあるが，ポットの土壤面はタバン栽培の場合, 葉面 積 $(\mathrm{LA} 1 \approx 2)$ にくらべて小さく(約 $8 \%$ ), 縁から $5 \mathrm{~cm}$ 程度以上も凹んでいて，ほとんど葉によつて覆われてい るので, ここからの蒸発は蒸散にくらべて 3〜 4\%程度 (Table 1) と小さかつたので,これも蒸散に含めた。

室内外のいわゆる蒸発力を比較するために, 万紙面蒸 発計(大田計器製)を用いた。これは直径 $3.3 \mathrm{~cm}$ の水平 白色ろ紙面からの蒸発量を小さな水槽から給水し, 水面 の降下をフロート式にペン書きさせるもので，1週間巻 きで蒸発速度の日变化がよみとれる特色がある (Fig 1)。

1）ポット試験に护ける土壤面蒸発の割合

タバコ（ブライトェロー）を 4 月27日に播種し，6月 2 日にa/5, 000 ポットに移植して育て，8月 4 日〜 11日 に測定を行なつた。土壤水分は飽和度で $20,40,60,80$ $\%$ の 4 区で，各区 5 ポットおよびブランクポット1（約 $50 \%$ 飽和度）の計 21 ッットである。土壤は秦野の火山灰 土を $2 \mathrm{~mm}$ でふるつたもので,これに $\mathbf{N}, \mathrm{P}, \mathrm{K}$ おのお の約 $1 \mathrm{~g} /$ ポットを添加した。土壤の充填方法および水分 ・養分の調整方法の詳細は別報1のとおりである。毎日 9 時に一定重量をで給水し減量により日蒸発散量を測定 したが, 生育にともなつてタバコ生体重の增加だけ目標 重量を修正する必要があるので, このため別の予備ポッ トにもタバコを植えて拈き約 1 週間毎に引き抜いて生体 重を適宜求めた。葉面積は全着葉の葉長・葉幅を測定 し, あらかじめ求めた係数 0.568 を乗じて算出した。

実験結果を Table 1 亿示す。

$80 \%$ 区では土壤面蒸発の比率が $10 \%$ 以上のものもみら れるが，これは過湿に生る生育障害を起したものであ り, 植物体は小さく枯上りの著しいことによつて表のよ 
らに葉面積も明らかに小さく異常であるので，これは除 外して考えれば，一般に土壤面蒸発の蒸散に対する比率 は $3 〜 4 \%$ とら小さな值に止まつていることが明らか である。

Table 1. The ratio of the soil surface evaporation to the transpiration from tobacco at the pot-culturing.

\begin{tabular}{|c|c|c|c|c|c|c|}
\hline & \multicolumn{2}{|c|}{$\begin{array}{c}\text { leaf area } \\
\left(\mathrm{cm}^{2}\right)\end{array}$} & \multicolumn{2}{|c|}{$\begin{array}{l}\text { transpiration } \\
\text { (g/day) }\end{array}$} & \multicolumn{2}{|c|}{ ratio $(\%)$} \\
\hline & 4/VIII & $11 / \mathrm{VII}$ & $4 \sim 6 /$ VIII & $7 \sim 11$ & $4 \sim 6 / \mathrm{VII}$ & $7 \sim 11$ \\
\hline $\begin{array}{l}20 \% \\
\text { plot }\end{array}$ & 4,256 & 4,687 & 830 & 1,226 & 3.6 & 4. 1 \\
\hline $\begin{array}{l}40 \% \\
\text { plot }\end{array}$ & 4,344 & 5,178 & 914 & 1,518 & 3. 3 & 3.3 \\
\hline $\begin{array}{l}60 \% \\
\text { plot }\end{array}$ & 4,017 & 5,200 & 818 & 1,314 & 3.7 & 3.8 \\
\hline $\begin{array}{l}80 \% \\
\text { plot }\end{array}$ & 2,714 & 3,450 & 384 & 722 & 11. 4 & 8.3 \\
\hline blank & & & 30 & 50 & & \\
\hline
\end{tabular}

2) 室内外に打けるタバコの昼夜の蒸散量

この場合には, ポット重量を 1 時間毎に $10 \mathrm{~kg}$ 精密二 稈天科により測定した。

実験結果を Table 2. に示す。

実験結果によれば夏の日中のタバコの蒸散は室外にく らべて常に室内は少なく, その平均比率は0.75であるこ とがわかる。

つぎに，1日の時刻別蒸散量は Table 2.から，昼間 は空外の方が多いのに対して夜間は反対に室内の方がか なり多く，1日の合計ではほとんど等しい值を示してい る。ところで, 室外における蒸散は自然条件下であるた
め, 温湿度・風速などの変動の影響を複雑にらけるの で,このような短期間の測定結果だけからでは室内外の 蒸散を十分に比較検討することはできない。また，年間 の比較を行ならためにはタバュを用いることができない ので, 葉面蒸発に最も近い蒸発計として, 万紙面蒸発計 を用いて以下の実験を行なつた。

\section{3）万紙面蒸発計による室内外蒸発量の測定}

自記記録の例を Fig. 1 に, 1 年間の測定結果を Table 3. に示す。

冬期にはしばしば室外の蒸発計が氷結したので $12 \sim 3$ 月の蒸発量は過小かつ不正確と考えられるが, 年間を通 じて明らかに室内の方が蒸発量が大であると言いらる。

Table 3. では, 各月とも室内の方が大であり，年間合 計では室外の1.75倍となつている。

つぎに Table 4. に四孝の代表例について昼夜別蒸発

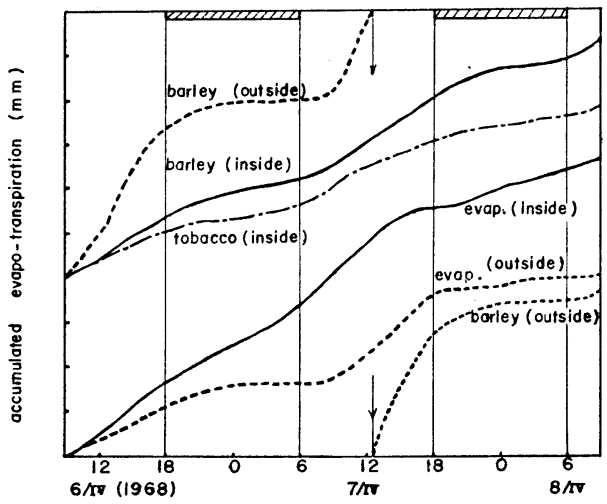

Fig. 1 The evopo-transpiration records obtained by the recording evapo-transpirometer.

Table 2. The transpiration from tobacco at the inside and outside of the air-conditioned glasshouse.

$\left(\mathrm{mg} / \mathrm{cm}^{2}\right)$

\begin{tabular}{c|c|c|c|c|c|c|c}
\hline time & $9 \sim 10$ & $10 \sim 12$ & $12 \sim 14$ & $14 \sim 16$ & day & $16 \sim 9$ & day and night \\
\hline inside & 24.7 & 52.4 & 46.3 & 12.9 & 136.3 & 61.8 & 198.1 \\
outside & 26.5 & 55.1 & 49.3 & 22.4 & 153.3 & 41.9 & 195.2 \\
in/out & 0.93 & 0.95 & 0.94 & 0.58 & 0.89 & 1.48 & 1.01 \\
\hline
\end{tabular}

$26 \sim 27 /$ VIII

Table 3. The evaporation from blot-paper-evaporimeter at the inside and outside of the house.

(nm)

\begin{tabular}{l|r|r|r|r|r|r|r|r|r|r|r|r|r}
\hline \hline month & XII & I & II & III & IV & V & VI & VII & VII & IX & X & XI & sum \\
\hline inside & 128.3 & 153.8 & 135.1 & 143.3 & 121.7 & 121.6 & 116.6 & 86.9 & 104.1 & 101.2 & 71.9 & 96.7 & $1,381.2$ \\
outside & $61.3^{*}$ & $66.0 *$ & $34.3^{*}$ & $65.5^{*}$ & 55.3 & 43.8 & 100.9 & 67.9 & 98.3 & 80.9 & 68.3 & 47.7 & 790.2 \\
in/out & 2.09 & 2.33 & 3.94 & 2.19 & 2.20 & 2.78 & 1.16 & 1.28 & 1.06 & 1.25 & 1.05 & 2.03 & 1.75 \\
\hline
\end{tabular}

* sometimes frosted. 
Table 4. The evaporation of daytime and nighttime at the inside and outside of the house.

\begin{tabular}{|c|c|c|c|c|c|c|c|c|c|c|c|c|}
\hline \multirow{2}{*}{$\frac{\text { date }}{\text { time }}$} & \multicolumn{3}{|c|}{$17 \sim 19 / \mathrm{I}$} & \multicolumn{3}{|c|}{$6 \sim 8 / \mathrm{IV}$} & \multicolumn{3}{|c|}{$26 \sim 28 / \mathrm{VII}$} & \multicolumn{3}{|c|}{$8 \sim 10 / X$} \\
\hline & day & night & $\mathrm{d} / \mathrm{n}$ & day & night & $\mathrm{d} / \mathrm{n}$ & day & night & $\mathrm{d} / \mathrm{n}$ & day & night & $\mathrm{d} / \mathrm{n}$ \\
\hline inside & 6.7 & 10.2 & 0.7 & 7.7 & 6.3 & 1. 2 & 7.7 & 4.4 & 1.8 & 4.5 & 3.0 & 1.5 \\
\hline outside & 7.9 & 2.3 & 3.4 & 6.8 & 1.9 & 3.6 & 9.6 & 0.9 & 10.7 & 7.6 & 1.7 & 4.5 \\
\hline
\end{tabular}

daytime $6 \sim 18 \mathrm{~h}$, nighttime $18 \sim 6 \mathrm{~h}$. Hatano E48 glasshouse 1967.

Table 5. The saturation deficit of humidity at the inside and outside of the house.

(\%)

\begin{tabular}{|c|c|c|c|c|c|c|c|c|}
\hline \multirow{2}{*}{ date time } & \multicolumn{2}{|c|}{$17 \sim 19 / \mathrm{I}$} & \multicolumn{2}{|c|}{$6 \sim 8 / \mathrm{VI}$} & \multicolumn{2}{|c|}{$26 \sim 28 / \mathrm{VII}$} & \multicolumn{2}{|c|}{$8 \sim 10 / X$} \\
\hline & day & night & day & night & day & night & day & night \\
\hline inside & 46 & 46 & 49 & 28 & 49 & 10 & 37 & 23 \\
\hline outside & 48 & 29 & 52 & 19 & 33 & 9 & 52 & 9 \\
\hline
\end{tabular}

day $=(10 \mathrm{~h}+14 \mathrm{~h}) / 2, \quad$ night $=(2 \mathrm{~h}+20 \mathrm{~h}) / 2$.

量を示す 。

これによれば，室外では昼夜の差が著しいのに対して 室内では，かなりこの差が小さい点に相異がみられる。 室内では夜間の方が昼間よりも蒸発量が大である場合さ えも認められる。Fig. 1 は同一紙上に室内と室外の記録 をあわせて書き写したものであるが, 室内の蒸発は室外 とは大きく異なつて昼夜の変動の少ない特色が明らかで ある。

また, Table 4 について, 昼の值だけでみれば, 4 月 を除いて室外の方が苜発量は大であるが，夜間は例外な く室内の方が大である。したがつて年間を通じて夜間に は室内の植物は室外よりもかなり乾燥状態にあるといら ことができる。

晴天の日中, 戋場では上位の葉温は気温よりもかなり 上昇するが，曇雨天をもらくめて全着葉について考えれ ば葉温と気温とほとれ泀ど著しく異なることはないとみ られる。ぬた, 空気調和ガラス室内では一般に葉温は日 中もほとんど気温と等しい2。。したがつて簡単のため葉 温は気温に等しく，その温度で葉表面は飽和湿度になつ ていると仮定すれば, 気流や熱伝達の影響をも無視し て, 蒸散は室内外ともにとの飽差, すなわち100-相対湿 度に概略比例するとみなすことができよう。それで室内 (ベッド上, 植物日陰) 扣よび 室外 (気象観測所) にお ける湿度の自記記録からもまた, 昼夜の室内外の蒸散力 が推定される。

このため, Table 4. と同一日の湿度記録から平均飽 差を求めた結果を Table 5. に示す。

これによると, 昼間の值は 7 月を除いて常に室外が弥
発力が高く, 夜間は例外なく室内が高くなつており, Table 5. と一般的傾向はよく一致した結果が示され, 湿度記録からも蒸発力が十分に推定されることがわか る。

4) 植物自記蒸散計による室内外蒸散量の測定

以上は蒸発計蒸発量についての実験であるが，しかし 植物体からの蒸散は蒸発とはやや異なり, 夜間には気孔 が閉塞し，日中には直達日射の影響を受けることから， 昼夜の蒸散量比などでは蒸発の場合よりも大きく, 相異 がみられるのではないかと考えられる。このことを実際 に植物を用いて実証するため前述のろ紙面蒸発計を用 い, ろ紙の代りに大麦抎よびタバコの小苗を植えて水耕 式に裁培し, 蒸散量の日変化を記録させる方法を考案し た。この装置 (Fig. 2) は小型軽量で蒸散量の時間変化 を細かく知ることができて便利である。この場合は室内 外とも日なたに置いて蒝散量を测定した (Fig. 1)。2 日間の昼夜の積蒸発量を Table 6 に示す。

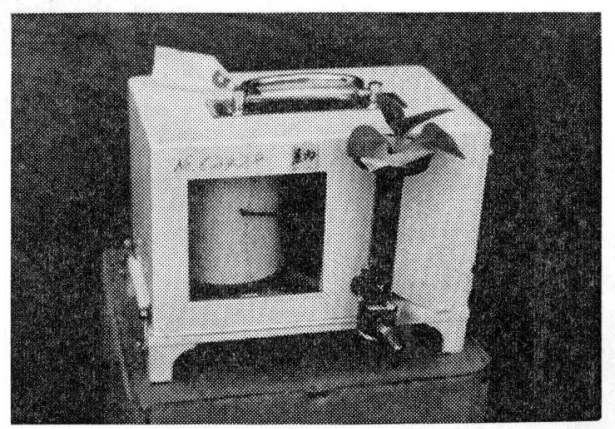

Fig. 2 可搬式自記蒸散計 
Table 6. The accumulated evapo-transpiration of daytime and nighttime.

\begin{tabular}{c|c|c|c|c}
\hline \multicolumn{2}{c|}{ plant } & day & night & $\mathrm{d} / \mathrm{n}$ \\
\hline \multirow{4}{*}{ inside } & tobacco & 2.7 & 1.1 & 2.5 \\
& barley & 3.6 & 1.8 & 2.0 \\
& blot paper & 4.0 & 2.6 & 1.5 \\
\hline \multirow{3}{*}{ outside } & barley & 8.3 & 1.4 & 5.9 \\
& blot paper & 3.2 & 0.9 & 3.6 \\
\hline
\end{tabular}

same two days shown in Fig. 1.

まず, Fig. 1 から蒸散も蒸発と類似し室内では室外に 比して昼夜の変動がかなり小さいことが明らかである。 また，タバコと大麦では大差なく，いずれも夜間にくら べて昼間の蒸散が著しい。これを昼夜の蒸散量の比でみ ると Table 6 より, 明らかに室内で昼夜の変動は小さ く, かつ, 蒸発計にくらべて植物からの蒸散でこの比が 大となつており，気孔の開閉の影響があらわれているも のと推察される。

このように室内植物の蒸散が室外と異なることは, 空

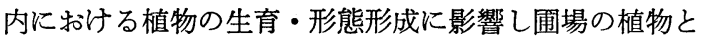
は相異したものが育成されることも考えられるので，室 内植物についての生理実験などでは，このような点につ いて一層の検討を要するのではないかと考えられる。

\section{2. 摘 要}

空気調和ガラス室の内外で蒸数がどのように異なるか を検討した。

蒸発計蒸発量は年間を通じて明らかに室内の方が室外 よりも大であつた。また, 昼夜別蒸発量では昼は室外が 蒸発が大であるが, 夜は例外なく室内が大であつた。こ のことは同時期の室内外の飽差からも裏付けられた。

植物からの蒸散速度の時間変化を明らかにするため に, 可搬式の小型自記蒸散計を考案した。この記録例か ら, 蒸散も蒸発と同様に, 室内は室外に比して昼夜の変 動が小さいことが示されたが，また，この昼夜の比は蒸 発のそれよりも明らかに大であつた。

総括的に, 室内の蒸散は昼夜の変動が比較的小さく, 昼間は概して室外よりも少ないが，夜間は大である特色 がある。

\section{引用 文 献}

1）小倉喏幸・久米英夫（1967）：ポット試験におけ る土壌の充填方法と容水量, 日土肥，38，275279.

2）小倉楉幸（1968）：空気調和ガラス室の純放射お よび短波放射について，農業気象，24，1-5.

\section{Summary}

The difference in transpiration between the inside and the outside of the air-conditioned glasshouse (25$18^{\circ} \mathrm{C}, 50-90 \% \mathrm{RH}$ ) is studied.

The evaporation from an evaporimeter has been clearly larger at the inside than at the outside throughout a year (Table 3). The evaporation at daytime has usually been larger at the outside than at the inside, while at nighttime the contrary has been the case (Table 4.). The data of saturation deficits (100RH) of air at the inside and outside of the house (Table 5.), support the above results.

In order to measure the hourly rate of transpiration from a small plant, a portable recording transpirometer has been devised (Fig. 2).

The records (Fig. 1) show clearly that the transpiration as well as the evaporation varies less with time at the inside than at the outside. The day-night ratio of transpiration is larger than that of evaporation (Table 6).

In conclusion, the transpiration at the inside varies relatively little throughout the day The daytime. transpiration is usually smaller inside, but at night the reverse is the case. 